\title{
Calcium hydroxide associated with a new vehicle: Psidium cattleianum leaf extracts. Tissue response evaluation
}

\begin{abstract}
Diego VALENTIM(a)
Carlos Roberto Emerenciano BUENO(b) Vanessa Abreu Sanches MARQUES ${ }^{(b)}$ Ana Maria Veiga VASQUES(b) Marina Tolomei Sandoval CURY(b) Luciano Tavares Angelo CINTRA ${ }^{(b)}$ Eloi DEZAN-JUNIOR ${ }^{\text {(b) }}$
\end{abstract}

(a) Centro Universitário do Distrito Federal - UDF, School of Dentistry, Department of Endodontics, Brasilia, DF, Brazil.

(b) Universidade Estadual Paulista - UNESP, Araçatuba School of Dentistry, Department of Endodontics, Araçatuba, SP, Brazil.

Declaration of Interests: The authors certify that they have no commercial or associative interest that represents a conflict of interest in connection with the manuscript.

\section{Corresponding Author:}

Eloi Dezan Junior

E-mail: dezan@foa.unesp.br

https://doi.org/10.1590/1807-3107BOR-2017.vol31.0043

Submitted: Oct 18, 2016

Accepted for publication: Mar 27, 2017

Last revision: Apr 17, 2017

\begin{abstract}
The aim of this study was to evaluate edemogenic activity and subcutaneous inflammatory reaction induced by Psidium cattleianum leaf extracts associated with $\mathrm{Ca}(\mathrm{OH})_{2}$. Thirty male Wistar rats, split equally into three groups [aqueous extract $+\mathrm{Ca}(\mathrm{OH})_{2}$; ethanolic extract $+\mathrm{Ca}(\mathrm{OH})_{2}$; and propylene glycol $+\mathrm{Ca}(\mathrm{OH})_{2}$ ], were assessed every $3 \mathrm{~h}$ or $6 \mathrm{~h}$ (five animals in each period). Under general anesthesia, $0.2 \mathrm{~mL}$ of $1 \%$ Evans blue per $100 \mathrm{~g}$ of body weight was injected into the penile vein and each combination to be evaluated was subcutaneously injected into the dorsal region $30 \mathrm{~min}$ thereafter. Edemogenic activity was analyzed by spectrophotometry $(\lambda=630 \mathrm{~nm})$. For inflammatory reaction analysis, 50 rats received four polyethylene tubes (three experimental groups) and an empty tube (control group). The assessments were made at 7, 15, 30, 60, and 90 days, followed by hematoxylin-eosin staining and by the assignment of scores for evaluation of tissue response intensity. Ethanolic extract $+\mathrm{Ca}(\mathrm{OH})_{2}$ yielded the largest edemogenic activity at $3 \mathrm{~h}$. Intergroup differences at $6 \mathrm{~h}$ were not significant. The histological analysis showed progressive repair over time $(\mathrm{p}<0.05)$ and aqueous and ethanolic extracts produced similar responses to those of the control and $\mathrm{Ca}(\mathrm{OH})_{2}+$ propylene glycol groups. Psidium cattleianum leaf extracts used as $\mathrm{Ca}(\mathrm{OH})_{2}$ vehicles evoked similar tissue response when compared to $\mathrm{Ca}(\mathrm{OH})_{2}$ associated with propylene glycol.
\end{abstract}

Keywords: Inflammation; Edema; Plants, Medicinal; Plant Extracts

\section{Introduction}

Microorganisms and their products are present in pulp and periapical diseases ${ }^{1,2,3,4}$ and may be found in dental pulp necrosis, in persistent or refractory infections, and throughout the root canal system. ${ }^{5,6}$ Even after cleaning and shaping the root canal with proper sodium hypochlorite irrigation, microorganisms may survive, especially in the apical third or in isthmus, due to the anatomic complexity of the root canal system. ${ }^{78}$

Many drugs have been tested over the years to reduce bacterial load, such as calcium hydroxide $\left[\mathrm{Ca}(\mathrm{OH})_{2}\right]$, one of the most widely used endodontic intracanal medications. ${ }^{9,10} \mathrm{Ca}(\mathrm{OH})_{2}$ acts by direct contact, but its action against microorganisms that penetrate deep into dentinal tubules may be impaired. ${ }^{11}$ 
Contact time is another factor to be considered. Sjögren etal. ${ }^{12}$ recommended using an interappointment medication to enhance the antibacterial effects of instrumentation, reducing bacterial count, and they proved that more than 7 days are required for its high efficacy. However, some microorganisms such as Enterococcus faecalis and Candida albicans are more resistant to $\mathrm{Ca}(\mathrm{OH})_{2}{ }^{6,13,14}$

Different microorganisms exhibit different levels of resistance to $\mathrm{Ca}(\mathrm{OH})_{2}$ activity, and new vehicles or products that improve the effects of $\mathrm{Ca}(\mathrm{OH})_{2}$ are being explored.

Psidium cattleianum belongs to the Myrtaceae family and is commonly found in the American tropics and locally known as "araçá-do-campo" (field guava) or "araçá comum" (common guava). ${ }^{15,16}$ Psidium spp. are used to treat various diseases (e.g., scurvy, ${ }^{17}$ cough, and lung disease ${ }^{18}$ ) and as anti-inflammatory and hemostatic agents. ${ }^{19,20}$ In addition, plants belonging to this species decrease the metastasis of cancer cells. ${ }^{21}$

Psidium cattleianum leaf extract has demonstrated antimicrobial activity and inhibits the growth of microorganisms such as Streptococcus mutans, Porphyromonas gingivalis, Prevotella intermedia, Fusobacterium nucleatum, Actinobacillus actinomycetemcomitans, and E. faecalis, ${ }^{22}$ killing S. mutans when applied at high concentrations or reducing lactic acid production when used at low concentrations. ${ }^{23}$

A microbiological research study revealed the potential of Psidium cattleianum ethanolic extract when used as a vehicle for $\mathrm{Ca}(\mathrm{OH})_{2}$, which boosted antimicrobial activity against $E$. faecalis and achieved total inhibition within $24 \mathrm{~h} .{ }^{24}$ According to Medina et al. (2011), ${ }^{25}$ the abundance of phenolic compounds in Psidium cattleianum extracts was positively correlated with their antioxidant, antimicrobial, and antiproliferative effects.

Since the combination of Psidium cattleianum leaf extracts used as vehicle for $\mathrm{Ca}(\mathrm{OH})_{2}$ has already proven effective in eliminating $E$. faecalis, tissue response evaluation is necessary as a preliminary compatibility test, and this may aid in endodontic therapy in the future.

The aim of this study was to evaluate the tissue response of rats to aqueous and ethanolic leaf extracts of Psidium cattleianum as a vehicle for $\mathrm{Ca}(\mathrm{OH})_{2}$ through edemogenic and microscopic analyses.

\section{Methodology}

\section{Animals}

Eighty male Wistar albino rats (3 to 4 months old) weighing between 200 and $250 \mathrm{~g}$ were assessed: 30 animals for the analysis of edemogenic activity (10 for each one of the three extracts, and five animals for two assessment periods: at $3 \mathrm{~h}$ and $6 \mathrm{~h}$ ) and 50 for subcutaneous implantation (10 for each experimental time period $-7,15,30,60$, and 90 days). The animals were kept in temperature-controlled rooms and received water and food ad libitum. This study was approved by the local Ethics Committee on the Use of Animals (CEUA, process no. 07457/2010).

\section{Preparation of extracts}

Psidium cattleianum leaves were obtained from the Araçatuba School of Dentistry, Universidade Estadual Paulista - UNESP, Araçatuba, SP, Brazil. The specimen (HLF2006/7) was deposited at the Pharmacology and Research Herbarium, Laboratory of Phytotherapy, São José do Rio Preto, Brazil. The leaves free from pests or diseases were washed and dried at $40{ }^{\circ} \mathrm{C}$ until they were brittle. The leaves were immediately ground to a powder.

The preparation of ethanolic and aqueous extracts followed Machado et al. ${ }^{26}$ For ethanolic extract preparation, $20 \mathrm{~g}$ of powdered leaves was mixed with $250 \mathrm{~mL}$ of $80 \%$ ethanol. The mixture was then manually stirred inside an amber bottle for $3 \mathrm{~min}$, 5 times a day, for 12 days. Subsequently, the mixture was filtered. The product was sterilized by filtration using a $0.22-\mu \mathrm{m}$ cellulose ester membrane (Millipore ${ }^{\mathrm{TM}}$, Billerica, USA). For aqueous extract preparation, $20 \mathrm{~g}$ of powdered leaves was added to $250 \mathrm{~mL}$ of distilled water and boiled at $100^{\circ} \mathrm{C}$ for $5 \mathrm{~min}$; the mixture was maintained at $55^{\circ} \mathrm{C}$ for $1 \mathrm{~h}$ and at room temperature for $72 \mathrm{~h}$ being stirred every $24 \mathrm{~h}$. The solution was then filtered and sterilized according to the method described above.

After extract preparation, the following combinations were mixed at a ratio of $1 \mathrm{~g}$ of $\mathrm{Ca}(\mathrm{OH})_{2}$ to $1 \mathrm{~mL}$ of the vehicle: 
a. aqueous extract $+\mathrm{Ca}(\mathrm{OH})_{2}$,

b. ethanolic extract $+\mathrm{Ca}(\mathrm{OH})_{2}$,

c. propylene glycol $+\mathrm{Ca}(\mathrm{OH})_{2}$.

\section{Edemogenic activity analysis}

Thirty animals were intramuscularly anesthetized with xylazine $(10 \mathrm{mg} / \mathrm{kg})$ and ketamine $(25 \mathrm{mg} / \mathrm{kg})$ and received an intravenous injection of 1\% Evans blue solution - $0.2 \mathrm{~mL}$ per $100 \mathrm{~g}$ of body weight (Evans Blue; Difco Lab. Detroit, Michigan, USA) into the penile vein. After $30 \mathrm{~min}$, the animals were divided into three groups $(\mathrm{n}=10)$, and each animal was injected with $0.1 \mathrm{~mL}$ of each combination (A, B, or $\mathrm{C}$ ) using an insulin syringe with a $0.70 \times 25 \mathrm{~mm}$ hypodermic needle $\left(22 \mathrm{G} \times 11 / 4^{\prime \prime}\right)$ in the dorsal region, next to the tail, using the midline as reference. ${ }^{26}$ Edema formation was quantified at $3 \mathrm{~h}$ and $6 \mathrm{~h}$.

After $3 \mathrm{~h}$ and $6 \mathrm{~h}$, five animals from each group were killed with an anesthetic overdose. The back of each animal was shaved, and an edematous area was evidenced and removed with a safety margin. The specimens were standardized to $23 \mathrm{~mm}$ in diameter, perforated, and placed into individual bottles containing $4 \mathrm{~mL}$ of formamide (Vetec Química, RJ, Brazil). After $72 \mathrm{~h}$ at $45^{\circ} \mathrm{C}$, gauze filtration was performed and absorbance of the specimens was measured using a spectrophotometer at $630 \mathrm{~nm}{ }^{26}$

\section{Subcutaneous implants}

Fifty rats (10 for each experimental period - 7, $15,30,60$, and 90 days), received four subcutaneous implants corresponding to each experimental group (A-C) or an empty tube (control D).

Two hundred polyethylene tubes (Abbott Labs of Brazil, São Paulo, SP, Brazil), with an outer diameter of $1.6 \mathrm{~mm}$ and length of $7.0 \mathrm{~mm}$, were filled with the test materials using an insulin syringe and a hypodermic needle $\left(22 \mathrm{G} \times 11 / 4^{\prime \prime}\right)$. The animals were anesthetized as previously described and the dorsal region was shaved before antisepsis with $5 \%$ iodine solution. A 1-cm incision was performed in the shaved area with a 15c blade. Each animal received four tubes followed by a $4-0$ silk suture. ${ }^{26}$

The animals were euthanized with anesthetic overdose within $7,15,30,60$, and 90 days after implantation. The tubes and the surrounding tissues were removed and fixed in 10\% formalin at $\mathrm{pH}$ 7.0. The specimens were processed and embedded in glycol methacrylate. Serial 3- $\mu \mathrm{m}$ sections were obtained for hematoxylin-eosin staining. Tissue reaction was evaluated as follows: score 0 - no inflammatory cell; score 1 - fewer than 25 cells; score 2 - between 25 and 125 cells; and score 3 - 125 or more cells. A fibrous capsule was considered to be thin when its thickness was less than $150 \mu \mathrm{m}$ and thick when it was greater than $150 \mu \mathrm{m} \cdot{ }^{26,27,28}$

The results obtained for edemogenic activity were analyzed by two-way analysis of variance (ANOVA) and Tukey's test, whereas the results of the histological examination were analyzed by the Kruskal-Wallis test. The significance level was set as $p<0.05$ for all statistical analyses.

\section{Results}

\section{Edemogenic activity analysis}

Ethanolic extract $+\mathrm{Ca}(\mathrm{OH})_{2}$ revealed greater edema formation at $3 \mathrm{~h}$ compared to the other groups $(p<0.05)$. There was no statistical difference between the groups $(p>0.05)$ at $6 h$; however, the group treated with ethanolic extract $+\mathrm{Ca}(\mathrm{OH})_{2}$ had a lower incidence of edema, whereas all the other groups showed a higher incidence, $\mathrm{p}>0.05$ (Figure 1).

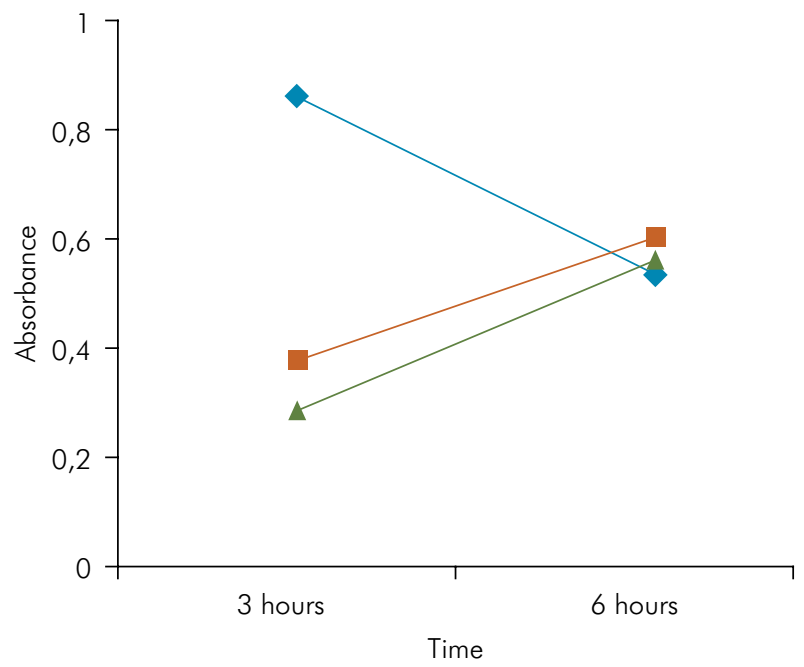

Ethanolic $\longrightarrow$ Aqueous $\quad-$ Propylene glycol

Figure 1. Graphical representation of mean value of edema in both periods studied. 


\section{Histological analysis}

\section{Aqueous extract $+\mathrm{Ca}(\mathrm{OH})_{2}$ (Group A)}

A moderate number of inflammatory cells were observed on days 7 and 15, indicating presence of lymphocytes, neutrophils, eosinophils, macrophages, and a thick fibrous capsule (Figure $2 \mathrm{~A}, \mathrm{E}$ ). The intensity of the inflammatory infiltrate decreased and thinning of the fibrous capsule was observed after 30, 60, and 90 days; the number of inflammatory cells observed on day 90 was significantly different from those observed on day 7, p $<0.05$, (Figures 2 I,M,Q and Figure 3).

Ethanolic extract $+\mathrm{Ca}(\mathrm{OH})_{2}$ (Group B)

A moderate number of inflammatory cells were observed on days 7 and 15, indicating

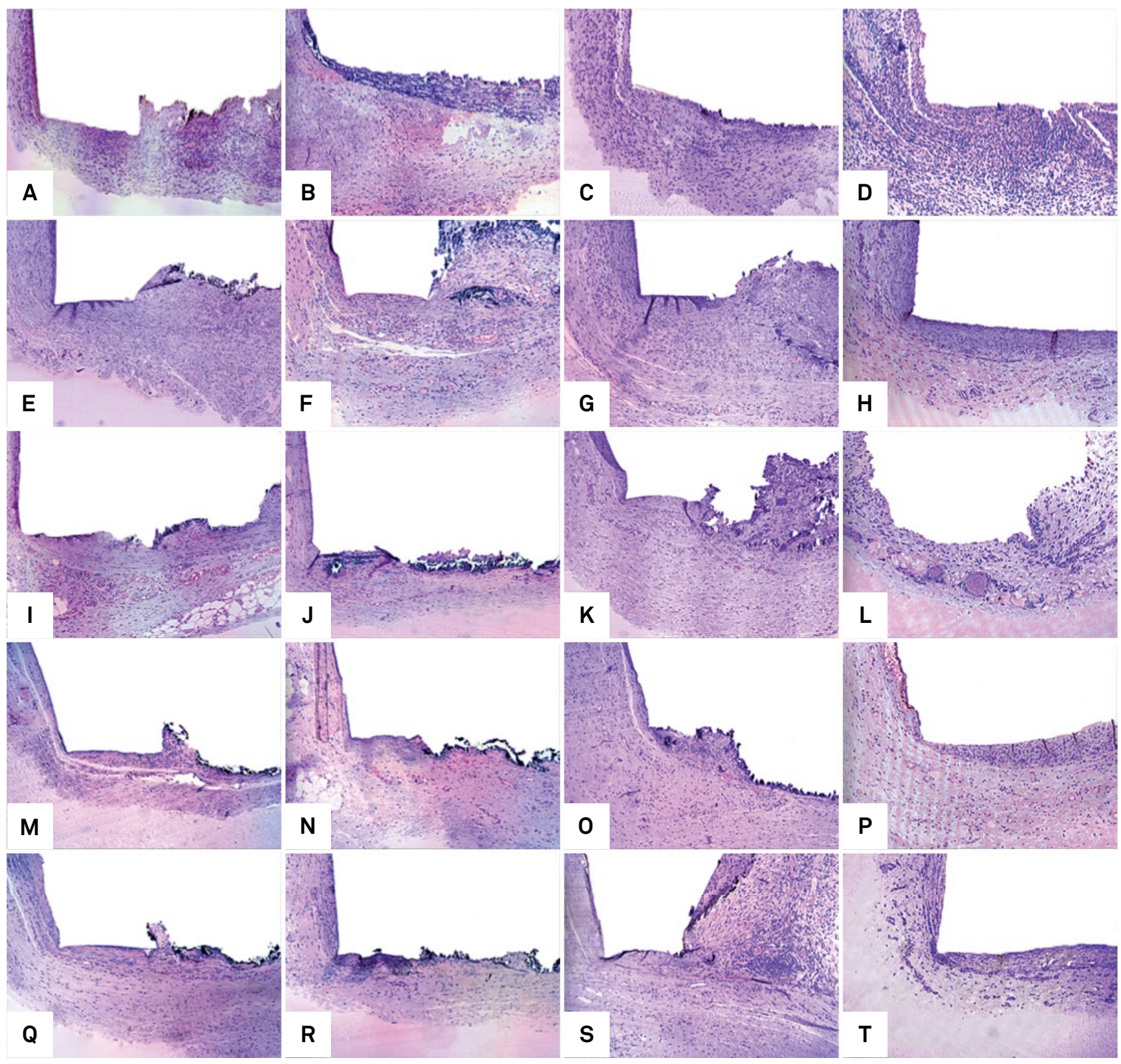

Figure 2. Histological analysis of experimental groups on postoperative days 7, 15, 30, 60 and 90 (HE, 100x). 


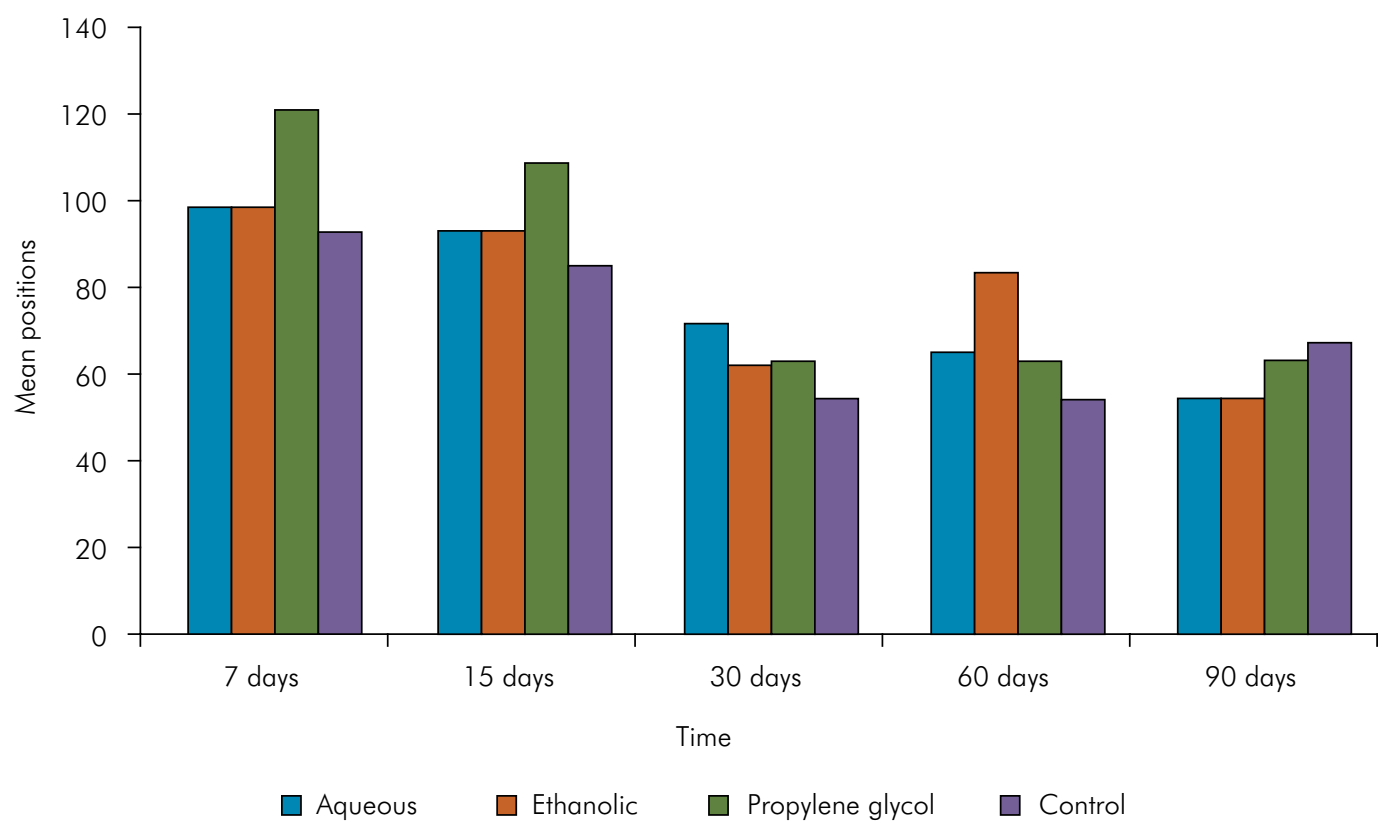

Figure 3. Graphical representation of the position occupied by the mean scores of the groups in the four periods studied.

presence of lymphocytes, neutrophils, eosinophils, macrophages, and a thick fibrous capsule (Figure 2 B,F). The intensity of the inflammatory infiltrate decreased $(\mathrm{p}<0.05)$ and thinning of the fibrous capsule was also observed after 30,60, and 90 days (Figure 2 J,N,R and Figure 3).

\section{Propylene glycol $+\mathrm{Ca}(\mathrm{OH})_{2}$ (Group C)}

A moderate number of inflammatory cells were observed on days 7 and 15, indicating presence of lymphocytes, neutrophils, macrophages, eosinophils, and a thick fibrous capsule (Figure 2 C,G). After 30 days, the number of inflammatory cells and capsule thickness decreased ( $p>0.05$, Figure 2 K,O,S and Figure 3).

\section{Control - empty tube (Group D)}

Similarly to what was observed in the other groups, the control group showed a moderate number of inflammatory cells on days 7 and 15, indicating presence of lymphocytes, neutrophils, macrophages, and a thick fibrous capsule. (Fig.1 D,H). The number of inflammatory cells decreased, and thinning of the fibrous capsule was observed after days 30, 60, and 90. (Figure $2 \mathrm{~L}, \mathrm{P}, \mathrm{T}$ and Figure 3).

\section{Comparison between groups as a function of time}

When comparing time periods, repair improved over time, showing similar results between the initial periods - at 7 and 15 days ( $p>0.05$ ), and also in the final ones - at 30, 60 and 90 days (Figure 3).

No difference was observed between the different combinations in the experimental periods $(p>0.05$, Figure 3).

\section{Discussion}

Besides the beneficial antimicrobial properties of an intracanal medication, attention should be paid to its biological response. Based on this assumption, Holland et al. ${ }^{29}$ evaluated the association of intracanal medications and observed severe inflammatory response when using camphor alone. The same result was obtained by Soekanto et al. ${ }^{30}$ from the culture of rat dental pulp cells, indicating camphor cytotoxicity. However, the biocompatibility of camphorated paramonochlorophenol has been reported for its association with $\mathrm{Ca}(\mathrm{OH})_{2}$, probably due to the lower penetration of camphor into tissues, once $\mathrm{Ca}(\mathrm{OH})_{2}$ has a denaturing effect on connective tissue, reducing its cytotoxicity ${ }^{31,32}$. 
In an attempt to sidestep these limitations, association of $\mathrm{Ca}(\mathrm{OH})_{2}$ with other antibacterial substances has been suggested. With this purpose, Midena et al..$^{33}$ evaluated subcutaneous tissue response in rats and the antimicrobial activity of intracanal $\mathrm{Ca}(\mathrm{OH})_{2}$ with different substances and reported high inflammatory response with the addition of chlorhexidine. Notwithstanding, the antibacterial effect did not improve.

The choice of Psidium cattleianum leaf extract in this study is due to its previously described antimicrobial properties. ${ }^{22,24}$ The study by Brighenti et al..$^{23}$ demonstrated its antibacterial potential at high concentrations, killing $S$. mutans grown on biofilms. At low concentrations, the extract inhibited acid production by $S$. mutans and reduced the expression of proteins involved in general metabolism, glycolysis, and lactic acid production. Its biocompatibility was introduced by Ruviére et al. ${ }^{34}$

The antibacterial activity of $P$. cattleianum is due to the presence of phenolic compounds, which contain flavonoids (kaempferol, quercetin, and cyanidin) and an ellagic acid, known as tannin. ${ }^{35}$ According to Medina et al., ${ }^{25}$ the abundance of phenolic compounds is directly related to the antimicrobial effect. This phenolic toxicity to microorganisms is caused by enzyme inhibition by the oxidized form of the phenolic compound. ${ }^{36}$

The edemogenic activity analysis was performed using a vital dye (Evans Blue), which binds to albumin plasma protein. The presence of this dye at edematous sites allows quantification of the edema. ${ }^{37}$

The combination of ethanolic extract and $\mathrm{Ca}(\mathrm{OH})_{2}$ showed significantly larger edema formation at the initial $3 \mathrm{~h}$, probably because of the presence of ethanol. This group showed a decrease in edema formation after $6 \mathrm{~h}$, whereas the group treated with

\section{References}

\footnotetext{
1. Kakehashi S, Stanley HR, Fitzgerald RJ. The effects of surgical exposures of dental pulps in germ-free and conventional laboratory rats. Oral Surg Oral Med Oral Pathol. 1965;20(3):340-9. https://doi.org/10.1016/0030-4220(65)90166-0

2. Fabricius L, Dahlén G, Öhman AE, Möller AJR. Predominant indigenous oral bacteria isolated from infected root
}

the combination of aqueous extract and propylene glycol with $\mathrm{Ca}(\mathrm{OH})_{2}$ showed larger edema formation (Figure 2). These findings were consistent with those previously reported using the ethanolic extracts of Psidium cattleianum $^{34}$ and of Myracrodruon urundeuva ${ }^{26}$ administered separately.

The histological analysis demonstrated that the inflammatory reaction in the control group (empty tube) was similar to that which had been previously reported, indicating a minor tissue response caused by the polyethylene tube. ${ }^{28,38,39}$ The highest scores were observed on days 7 and 15, in the initial period, and were associated with the surgical trauma. The control and experimental groups showed similar levels of inflammation in early periods, and our findings were similar to those reported by Torneck. ${ }^{40}$ Because of a decrease in the influence of surgical procedure on day 30, a significant improvement was observed in inflammation in all groups, a characteristic that was maintained on days 60 and 90 .

This study shows that the aqueous and ethanolic leaf extracts of Psidium cattleianum used as a vehicle for $\mathrm{Ca}(\mathrm{OH})_{2}$ exhibited similar tissue response when compared to the propylene glycol and control groups.

\section{Conclusion}

Aqueous and ethanolic leaf extracts of Psidium cattleianum used as a vehicle for $\mathrm{Ca}(\mathrm{OH})_{2}$ show favorable tissue response, similarly to that obtained from the combination of $\mathrm{Ca}(\mathrm{OH})_{2}$ and propylene glycol, indicating that these extracts have promising applications in the field of dentistry.

\section{Acknowledgments}

The authors deny any conflict of interest.

\footnotetext{
canals after varied times of closure. Scand J Dent Res.

1982;90(2):134-44.

3. Tani-Ishii N, Wang CY, Tanner A, Stashenko P. Changes

in root canal microbiota during the development of rat periapical lesions. Oral Microbiol Immunol. 1994;9(3):129-35. https://doi.org/10.1111/i.1399-302X.1994.tb00048.x
} 
4. Pazelli LC, Freitas AC, Ito IY, Souza-Gugelmin MCM, Medeiros AS, Nelson-Filho P. Prevalence of microorganisms in root canals of human deciduous teeth with necrotic pulp and chronic periapical lesions. Pesqui Odontol Bras. 2003;17(4):367-71. https://doi.org/10.1590/S1517-74912003000400013

5. Safavi KE, Spangberg LS, Langeland K. Root canal dentinal tubule disinfection. J Endod. 1990;16(5):207-10. https://doi.org/10.1016/S0099-2399(06)81670-5

6. Evans M, Davies JK, Sundqvist G, Figdor D. Mechanisms involved in the resistance of Enterococcus faecalis to calcium hydroxide. Int Endod J. 2002;35(3):221-8. https://doi.org/10.1046/i.1365-2591.2002.00504.x

7. Wada M, Takase T, Nakanuma K, Arisue K, Nagahama F, Yamazaki M. Clinical study of refractory apical periodontitis treated by apicectomy Part 1. Root canal morphology of resected apex. Int Endod J. 1998;31(1):53-56. https://doi.org/10.1046/i.1365-2591.1998.t01-1-00123.x

8. Vera J, Siqueira JF Jr, Ricucci D, Loghin S, Fernández $\mathrm{N}$, Flores B et al. One- versus two-visit endodontic treatment of teeth with apical periodontitis: a histobacteriologic study. J Endod. 2012;38(8):1040-52. https://doi.org/10.1016/i.joen.2012.04.010

9. Holland R, Souza V, Nery MJ, Mello W, Bernabé PFE, Otoboni Filho JA. A histological study of the effect of calcium hydroxide in the treatment of pulpless teeth of dogs. Int Endod J. 1979;12(1)1524. https://doi.org/10.1111/j.1365-2591.1979.tb01255.x

10. Atila-Pektaş B, Yurdakul P, Gülmez D, Görduysus $O$. Antimicrobial effects of root canal medicaments against Enterococcus faecalis and Streptococcus mutans. Int Endod J. 2013;46(5):413-8. https://doi.org/10.1111/iej.12004

11. Siqueira JF Jr, Lopes HP. Mechanisms of antimicrobial activity of calcium hydroxide: a critical review. Int Endod J. 1999;32(5):361-9. https://doi.org/10.1046/i.1365-2591.1999.00275.x

12. Siögren U, Figdor D, Spångberg L, Sundqvist $G$. The antimicrobial effect of calcium hydroxide as a short-term intracanal dressing. Int Endod J. 1991;24(3):119-25. https://doi.org/10.1111/j.1365-2591.1991.tb00117.x

13. Orstavik D, Haapasalo M. Disinfection by endodontic irrigants and dressings of experimentally infected dentinal tubules. Endod Dent Traumatol. 1990;6(4):142-9. https://doi.org/10.1111/j.1600-9657.1990.tb00409.x

14. Estrela C, Estrela CRA, Pécora JD. A study of the time necessary for calcium hydroxide to eliminate microorganisms in infected canals. J Appl Oral Sci. 2003;11(2):133-7. https://doi.org/10.1590/S1678-77572003000200009

15. Pott A, Pott VJ. Plantas do Pantanal. Brasília, DF: Embrapa; 1994.

16. Silva S, Tassara H. Frutas do Brasil. São Paulo: Empresa das Artes; 1996.

17. Watt JM, Branehwizk MG. The medicinal and poisonous plants of southern and eastern Africa. London: E \& S Livingstone; 1969.
18. Batick MJ. Ethnobotany of palms in the neotropics. In: Prance GT, Kallunki JA, editors. Advances in economic botany: ethnobotany in the neotropics. New York: New York Botanical Garden; 1984. p. 9-23.

19. Lozoya X, Meckes M, Aboud- Zaid M, Tortoriello J, Nozzolillo C, Arnason JT. Quercetin glycosides in Psidium guajava L. leaves and determination of spasmolytic principle. Arch Med Res. 1994;25(1):11-5.

20. Jaiarj $P$, Khoohaswan $P$, Wongkrajang $Y$, Peungvicha P, Suriyawong P, Saraya ML et al. Anticough and antimicrobial activities of Psidium guajava Linn. leaf extract. J Ethnopharmacol. 1999;67(2):203-12. https://doi.org/10.1016/S0378-8741(99)00022-7

21. Im I, Park KR, Kim SM, Kim C, Park JH, Nam D et al. The butanol fraction of guava (Psidium cattleianum Sabine) leaf extract suppresses MMP-2 and MMP-9 expression and activity through the suppression of the ERK1/2 MAPK signaling pathway. Nutr Cancer. 2012;64(2):255-66. https://doi.org/10.1080/01635581.2012.642455

22. Gaetti-Jardim Junior E, Landucci LF, Arafat OK, Ranieiri RV, Ramos MMB, Ciesilski FIN et al. Antimicrobial activity of six plant extracts from the Brazilian savanna on periodontal pathogens. Int J Odontostomatol. 2011;5(3):249-56. https://doi.org/10.4067/S0718-381X2011000300008

23. Brighenti FL, Luppens SB, Delbem AC, Deng DM, Hoogenkamp MA, Gaetti-Jardim Junior E et al. Effect of Psidium cattleianum leaf extract on Streptococcus mutans viability, protein expression and acid production. Caries Res. 2008;42(2):148-54. https://doi.org/10.1159/000121439

24. Dezan Junior E, Sangalli J, Gomes-Filho JE, Gaetti-Jardim Junior E. Psidium cattleianum plus $\mathrm{Ca}(\mathrm{OH}) 2$ antimicrobial efficacy against Enterococcus faecalis. In: 88th IADR; 2010 Jul 15-16; Barcelona, Spain.

25. Medina AL, Haas LIR, Chaves FC, Salvador M, Zambiazi RC, Silva WP et al. Araçá (Psidium cattleianum Sabine) fruit extracts with antioxidant and antimicrobial activities and antiproliferative effect on human cancer cells. Food Chem. 2011;128(4):916-22. https://doi.org/10.1016/i.foodchem.2011.03.119

26. Machado AC, Dezan Junior E, Gomes-Filho JE, Cintra LTA, Ruviére DB, Zoccal R et al. Evaluation of tissue reaction to Aroeira (Myracrodruon urundeuva) extracts: a histologic and edemogenic study. J Appl Oral Sci. 2012;20(4):414-8. https://doi.org/10.1590/S1678-77572012000400005

27. Gomes-Filho JE, Watanabe S, Lodi CS, Cintra LT, Nery MJ, Filho JA et al. Rat tissue reaction to MTA FILLAPEX®. Dent Traumatol. 2012;28(6):452-6. https://doi.org/10.1111/j.1600-9657.2011.01096.x

28. Bueno CR, Valentim D, Marques VAS,

Gomes-Filho JE, Cintra LT, Jacinto RC et al. Biocompatibility and biomineralization assessment of bioceramic-, epoxy-, and calcium hydroxide-based sealers. Braz Oral Res. 2016;30(1):81. https://doi.org/10.1590/1807-3107BOR-2016.vol30.0081 
- Calcium hydroxide associated with a new vehicle: Psidium cattleianum leaf extracts. Tissue response evaluation

29. Holland R, Valdir S, Milanezi LA. Behaviour of pulp stump and periapical tissues to some drugs used as root canal dressings: a morphological study. Braz J Med Biol Res. $1969 ; 2(1): 13-23$.

30. Soekanto A, Kasugai S, Mataki S, Ohya K, Ogura H. Toxicity of camphorated phenol and camphorated parachlorophenol in dental pulp cell culture. J Endod. 1996;22(6):284-9. https://doi.org/10.1016/S0099-2399(96)80259-7

31. Leonardo MR, Silva LAB, Utrilla LS, Leonardo RT, Consolaro A. Effect of intracanal dressings on repair and apical bridging of teeth with incomplete root formation. Endod Dent Traumatol. 1993;9(1):25-30. https://doi.org/10.1111/j.1600-9657.1993.tb00456.x

32. Siqueira Junior JF, Uzeda M. Influence of different vehicles on the antibacterial effects of calcium hydroxide. J Endod. 1998;24(10):663-5. https://doi.org/10.1016/S0099-2399(98)80151-9

33. Midena RZ, Garcia RB, Cavenago BC, Marciano MA, Minotti PG, Ordinola-Zapata R et al. Analysis of the reaction of subcutaneous tissues in rats and the antimicrobial activity of calcium hydroxide paste used in association with different substances. J Appl Oral Sci. 2015;23(5):508-14. https://doi.org/10.1590/1678-775720140049

34. Ruviére DB, Machado AC, Novais RZ, Gaetti Jardim-Junior E, Dezan Junior E. Evaluation of the tissue response to inactivated microorganisms associated with aqueous and hydroalcoholic araça (Psidium cattleianum) solutions. J Appl Oral Sci. 2008;432

35. United States Department of Agriculture, National Genetic Resources Program, Agricultural Research Service. Phytochemical and ethnobotanical databases. Beltsville, MD: National Germplasm Resources Laboratory; 2005.

36. Mason TL, Wasserman BP. Inactivation of red beet betaglucan synthase by native and oxidized phenolic compounds. Phytochemistry. 1987;26(8):2197-202. https://doi.org/10.1016/S0031-9422(00)84683-X

37. Rutberg M, Spangberg E, Spangberg L. Evaluation of enhanced vascular permeability of endodontic medicaments in vivo. J Endod. 1977;3(9):347-51. https://doi.org/10.1016/S0099-2399(77)80064-2

38. Yaltirik M, Ozbas $H$, Bilgic B, Issever $H$. Reactions of connective tissue to mineral trioxide aggregate and amalgam. J Endod. 2004;30(2):95-9. https://doi.org/10.1097/00004770-200402000-00008

39. Gomes-Filho JE, Watanabe S, Bernabé PF, Costa MTM. A mineral trioxide aggregate sealer stimulated mineralization. J Endod. 2009;35(2):256-60. https://doi.org/10.1016/i.joen.2008.11.006

40. Torneck CD. Reaction of rat connective tissue to polyethylene tube implants. I. Oral Surg Oral Med Oral Pathol. 1966;21(3):379-87. https://doi.org/10.1016/0030-4220(66)90077-6 